\title{
WUJUD NYATA PERAN PEMUDA DAN ORGANISASI MASYARAKAT DALAM UPAYA PENINGKATAN KESEJAHTERAAN DI MASA PANDEMI COVID 19
}

\author{
Nurismalatri $^{1}$, Yuga Pratama ${ }^{2}$, Siti Aesah $^{3}$, Djoko prasetyo $^{4}$, \\ Siti Aisyah Nurrizqi Rahmadania ${ }^{5}$ \\ Universitas Pamulang \\ Email: dosen00996@unpam.ac.id
}

\begin{abstract}
The impact of handling the Covid-19 pandemic has begun to affect economic activity in terms of income, consumption, production, investment, as well as exports and imports. Indonesia's economic growth in the first quarter of 2020 was recorded at 2,97\%(yoy), lower than Bank Indonesia's estimate of 4,4\% (yoy). From the expenditure side, the decline in economic growth in the first quarter of 2020 was mainly influenced by lower domestic domestic demand. Household consumption was recorded at 2,84\% (yoy), much lower than the performance in quarter IV 2019 of 4,97\% (yoy). Investment also grew at slower pace of 1,7\%(yoy). In principle, there are three pillars in the development process of a country, anmely; state, private sector and sivil society. Civil society (humanitarian service institutions / social organizationa in improving welfare during the Covid 19 pandemic. In particular, the focus of this community service will be directed at the following three things:

1) Indicators of poverty reduction and improvement of community welfare

2) The form of the cntributin of youth and community organizations in reducing poverty in the South Tangerang environment

3) Forms of contribution form youth and community organizations in improving personal and enviromental welfare in South Tangerang

This activity uses a lecture, discussion and training approach that refers to phenomenology. Location of activities in the community organization Majelis Kampung Duha in pamulang, South Tangerang. The conclusion of this activity is that there are three formulas in an effort to realize the welfare of the community including : First, the participation of the community in working together to help the goverment. Second, zakat distribution, that with the existence of zakat, wealth will be distributed to those who have excessive assets with those in need. Third, economic growth seen from the increase in indovidual income. Fourth, indicators of the attainment of life welfare are also influenced by mental well-being where the sources is spiritual or religius values. Fifth, community development where there is active interaction between social workers and the community by forming social work programs. Sixth: community empowerment with a model that will be able to help the community to be able to control their life better in terms ef economic gain by being able to carry out economic activities.
\end{abstract}

Keywords: Youth, Community Organizations, Poverty, Welfare, Covid 19. 


\section{Abstrak}

Dampak penanganan pandemi COVID-19 mulai memengaruhi kegiatan ekonomi baik dari sisi pendapatan, konsumsi, produksi, investasi, serta ekspor dan impor. Pertumbuhan ekonomi Indonesia triwulan I 2020 tercatat 2,97\% (yoy), lebih rendah dari perkiraan Bank Indonesia 4,4\% (yoy). Dari sisi pengeluaran, penurunan pertumbuhan ekonomi triwulan I 2020 terutama dipengaruhi penurunan permintaan domestik. Konsumsi rumah tangga tercatat 2,84\% (yoy), jauh lebih rendah dibandingkan dengan kinerja pada triwulan IV 2019 sebesar 4,97\% (yoy). Investasi juga tumbuh melambat sebesar $1,7 \%$ (yoy). Secara prinsip, terdapat tiga pilar dalam proses pembangunan sebuah negara, yakni: state, private sector, dan civil society. civil society (lembaga pelayanan kemanusiaan/Organisasi Sosial) mempunyai porsi yang sama besar dengan dua pilar lainnya dalam menopang pembangunan negara yang dapat terwujud dalam bentuk kesejahteraan dan peningkatan ekonomi.

Fokus pengabdian kepada masyarakat ini adalah peran serta pemuda dan organisasi masyarakat dalam peningkatan kesejahteraan di masa pandemi covid 19. Secara khusus, fokus pengabdian kepada masyarakat ini akan diarahkan pada tiga hal berikut:

1) Indikator penurunan kemiskinan dan peningkatan kesejahteraan masyarakat

2) Bentuk kontribusi pemuda dan organisasi masyarakat dalam penurunan kemiskinan pada lingkungan Tangerang Selatan,

3) Bentuk kontribusi pemuda dan organisasi masyarakat dalam peningkatan kesejahteraan pribadi dan lingkungan Tangerang Selatan

Kegiatan ini menggunakan pendekatan ceramah, diskusi dan pelatihan yang mengacu pada fenomenologis. Lokasi kegiatan pada organisasi masyarakat Majelis Kampung Duha, Pamulang, Tangerang Selatan. Kesimpulan kegiatan ini ada tiga rumusan dalam upaya mewujudkan kesejahteraan masyarakat meliputi: Pertama, peran serta masyarakat dalam bekerja sama membantu pemerintah Kedua, penyaluran zakat, bahwa dengan adanya zakat maka akan terdistribusikan harta bagi mereka yang berlebihan harta dengan mereka yang membutuhkan Ketiga, adanya pertumbuhan ekonomi yang dilihat dari peningkatan pendapatan individu. Keempat, indikator pencapaian kesejahteraan kehidupan juga dipengaruhi oleh kesejahteraan mental dimana sumbernya adalah nilai nilai spiritual atau keagamaan. Kelima, pengembangan masyarakat dimana terdapat interaksi aktif antara pekerja sosial dan masyarakat dengan membentuk program kerja sosial. Keenam : pemberdayaan masyarakat dengan model model yang akan dapat membantu masyarkat untuk dapat menguasai kehidupannya untuk lebih baik dari segi perolehan ekonomi dengan cara mampu melakukan aktivitas ekonomi.

\section{Kata Kunci: Pemuda, Organisasi Masyarakat, Kemiskinan, Kesejahteraan, Covid 19.}




\section{A. PENDAHULUAN}

Dalam kurun waktu satu dekade tahun 2011-2020, krisis ekonomi global, berbagai bencana alam dan pandemi covid 19 yang saat ini terjadi di seluruh belahan dunia memicu bertambah luasnya permasalahan kesejahteraan sosial khususnya yang dihadapi oleh bangsa Indonesia. Konsekuensi logik dari kondisi ini adalah tergusurnya masyarakat yang kurang dan/atau tidak mampu dalam menghadapi perubahan tersebut. Tergusurnya masyarakat dalam proses perubahan tersebut tercermin dari (1) jumlah angka kemiskinan yang semakin besar sehingga tidak dapat mengakses fasilitas pelayanan kesehatan, pendidikan dan sumber kesejahteraan sosial secara memadai (2) meningkatnya kriminalitas (baik kuantitas maupun kualitas), (3) solidaritas (kebersamaan) masyarakat semakin melemah.

Tingkat kemiskinan tetap menjadi ukuran kesejahteraan masyarakat, data Badan Pusat Statistik (2020) bahwa per Agustus 2019 angka kemiskinan di Indonesia masih tinggi sebesar $19,16 \%$ atau 24,79 juta dari jumlah penduduk Indonesia secara keseluruhan, hal ini menunjukkan bahwa masih banyak menjadi pekerjaan rumah bagi kita semua. Kebijakan yeng dilakukan pemerintah di berbagai bidang tampaknya masih jauh dari apa yang menjadi cita-cita masyarakat dan para pencetus kemerdekaan yaitu kesejahteraan sosial. Diperparah dengan adanya pandemi covid 19, tentu diperlukan strategi strategi yang mengutamakan kepentingan rakyat agar tidak menambah penduduk yang berada di bawah garis kemiskinan.

Peningkatan negara yang terdampak virus Covid-19 di seluruh dunia seperti Amerika, Spanyol dan Italia membuat situasi ekonomi dunia semakin memburuk. Beberapa lembaga bahkan memprediksikan perlemahan ekonomi dunia, antara lain International Monetary Fund (IMF) yang memproyeksikan ekonomi global tumbuh minus di angka 3\%. Di Indonesia, berdasarkan Laporan Perkembangan Terkini Bank Indonesia (2020), dampak penyebaran Covid 19 terhadap kondisi perekonomian Indonesia yaitu penurunan permintaan masyarakat akibat pandemic Covid-19, termasuk dari sisi pendapatan masyarakat.

Banten yang merupakan salah satu provinsi di Indonesia juga secara khusus mengalami permasalahan ekonomi yaitu ekonomi Banten semester I-2020 terhadap semester I-2019 terkontraksi sebesar 2,15 persen. Dari sisi produksi, pertumbuhan negatif terjadi hampir semua lapangan usaha. Pertumbuhan terendah pada lapangan usaha Transportasi dan Pergudangan sebesar minus 25,54 persen. Sementara dari sisi pengeluaran terutama disebabkan oleh Komponen Pengeluaran Total Net Ekspor yang terkontraksi sebesar 25,37 persen.

Berdasarkan fenomena dan permasalahan pendidikan yang diungkapkan di atas, maka pengabdian kepada masyarakat (PKM) ini mengambil Tema "Wujud Nyata Peran Pemuda dan Organisasi Masyarakat Dalam Upaya Peningkatan Kesejahteraan di Masa Pandemi Covid 19" kepada masyarakat di Benda Baru, Pamulang, Tangerang Selatan.

\section{B. METODE PELAKSANAAN}

1. Khalayak Sasaran

Khalayak sasaran dalam kegiatan pengabdian pada masyarakat ini adalah para pemuda dan wara sekitar majelis kampung dhuha

2. Tempat dan Waktu

Kegiatan Pengabdian pada masyarakat ini dilaksanakan pada tanggal 08 Oktober-10

Oktober 2020

3. Metode Kegiatan

Metode kegiatan yang dilakukan dalam rangka menyukseskan kegiatan pengabdian ini, yaitu: 
a. Peralatan yang dibutuhkan untuk melaksanan kegiatan ini. Pada tahapan ini pelaksana memulai dengan melakukan koordinasi dengan instansi terkait.

b. Penentuan Lokasi. Pada tahap ini dilakukan kunjungan ke lokasi untuk menentukan tempat (lokasi). Dalam memilih lokasi, kami mempertimbangkan dengan jarak yang kami tempuh dari Universitas ke lokasi pengabdian.

c. Perancangan kebutuhan.

Adapun tahapan yang dilakukan dalam perancangan kebutuhan secara berurutan adalah sebagai berikut:

a. Perancangan materi peran orangtua dan masyarakat dalam pendidikan.

b. Perancangan materi hubungan masyarakat dengan sekolah

c. Perancangan alat.

Metode pendekatan yang digunakan dalam kegiatan ini adalah ceramah, diskusi dan pelatihan. Kegiatan pengabdian kepada masyarakat direncanakan pada :

Hari/Tanggal : Kamis - Sabtu/ 8-10 Oktober 2020

Waktu : :08.00-13.00 Wib

Tempat : Aula Kampung Dhuha

\section{HASIL DAN PEMBAHASAN}

Individu atau perseorangan, keluarga, kelompok, dan/atau masyarakat dapat menjdi Potensi dan Sumber Kesejahteraan Sosial karena dapat berperan serta untuk menjaga, menciptakan, mendukung, dan memperkuat penyelenggaraan kesejahteraan sosial. Konsep pembangunan kesejahteraan sosial menurut Suharto (2014) sejalan dengan pembangunan sosial (social development) yang di Indonesia sering mencakup bidang pendidikan, kesehatan, perumahan dalam arti luas. Pembangunan kesejahteraan sosial (social welfare development) didefinisikan sebagai pendekatan pembangunan yang bertujuan untuk meningkatkan kualitas hidup masyarakat melalui peningkatan modal ekonomi (economic capital), manusia (human capital), kemasyarakatan (societal capital), dan perlindungan (security capital) secara terintegrasi dan berkesinambungan. Berbagai solusi dalam rangka peningkatan kesejahteraan masyarakat diantaranya yaitu :

1. Kerjasama antara pemerintah dan masyarakat

Kontribusi organisasi dalam pembangunan kesejahteraan sosial baik di kota besar maupun pedesaan merupakan salah satu upaya untuk mengidentifikasi kondisi organisasi sosial; kontribusi organisasi sosial dalam pembangunan kesejahteraan sosial; program yang dapat memberikan akselerasi kontribusi organisasi sosial dalam pembangunan kesejahteraan sosial. Permasalahan sosial yang dijadikan konsentrasi antara lain: pelayanan anak terlantar dan berbagai permasalahannya, keluarga miskin, penyandang cacat, rumah tak layak huni meskipun masih terbaik. Realisasi kegiatan organisasi sosial telah mampu menjawab tuntutan kebijakan pemerintah, bahkan tuntutan agenda dunia. Keberadaan organisasi sosial di tengah masyarakat merupakan potensi besar dalam penyelenggaraan usaha kesejahteraan sosial. Potensi ini tidak akan optimal jika kurang mendapatkan perhatian instansi sektoral yang berkaitan langsung dan ruang yang lebih luas dalam penyelenggaraan usaha kesejahteraan sosial di Indonesia. Sebagai pilar partisipan, organisasi sosial dapat menjalin kemitraan dengan seluruh unit yang berada di Kementerian Sosial dan/atau instansi lain (baik pemerintah maupun swasta), dan dunia usaha yang mempunyai jangkauan program sampai ke tingkat kelurahan. 
2. Penyaluran zakat

Abbas (2005) mengemukakan bahwa Sistem kesejahteraan sosial yang berakar dalam tradisi Islam (The Islamic Welfare Effort) merupakan bagian dari agenda yang ikut mewarnai Interaksi antara Islam dan negara di Indonesia. Proses akomodasi negara terhadap sistem kesejahteraan sosial islam mulai menguat dengan pemberlakuan Undang undang No 38/1999 tentang pengelolaan zakat. Undang undang ini menjadi dasar hukum yang menempatkan sistem kesejahteraan sosial islam sebagai bagian penting dari kebijakan dan kesejahteraan sosial di Indonesia. zakat merupakan faktor yang memberikan kontribusi besar terhadap perekonomian masyarakat, terutama bagi masyarakat pedesaan.

3. Pertumbuhan ekonomi

Pertumbuhan ekonomi merupakan sarana untuk mencapai keadilan distributive, karena mampu menciptakan lapangan pekerjaan yang baru, dengan terciptanya lapangan kerja baru maka pendapatan riil masyarakat akan meningkat, dan ini merupakan salah satu indicator kesejahteraan dalam ekonomi Islam. Dengan adanya aktivitas ekonomi, maka seseorang dapat memenuhi kebutuhan hidupnya, menciptakan kesejahteraan bagi dirinya dan keluarganya serta dapat membantu orang lain yang sedang membutuhkan.

4. Nilai Nilai Spiritual

Berdasarkan hasil penelitian Sabah (2019), nilai-nilai spiritual dan kehidupan praktis dapat sejalan jika kita memajukan cahaya spiritual kesejahteraan sosial dan filantropi. Dengan memberi dunia suatu anugerah ideologi spiritual sosial kesejahteraan, kita dapat melakukan perjalanan spiritual manusia menuju perjalanan Suci dan melakukan a hubungan dengan Tuhan Yang Maha Kuasa. Faktanya adalah lingkaran pelayanan kemanusiaan itu demikian sangat luas sehingga setiap orang dapat membayar haknya di depan ini. Mereka melakukan kesejahteraan sosial untuk kesenangan Allah SWT dan hanya pahala yang diharapkan.

5. Pengembangan Masyarakat

Pengembangan Masyarakat (PM) adalah salah satu metode kerja sosial yang tujuan utamanya untuk memperbaiki kualitas hidup masyarakat melalui pendayagunaan sumbersumber yang ada pada mereka serta menekankan pada prinsip partisipasi sosial. Sebagai sebuah metode pekerjaan sosial, PM menunjuk pada interaksi aktif antara pekerja sosial dan masyarakat dengan mana mereka terlibat dalam proses perencanaan, pelaksanaan, pengawasan dan evaluasi suatu program pembangunan kesejahteraan sosial (PKS) atau usaha kesejahteraan sosial (UKS). PM meliputi berbagai pelayanan sosial yang berbasis masyarakat mulai dari pelayanan preventif untuk mencegah anak-anak terlantar atau diperlakukan salah (abused) sampai pelayanan kuratif dan pengembangan untuk keluarga yang berpendapatan rendah agar mereka mampu memenuhi kebutuhan dasarnya (Suharto, 2014).

6. Pemberdayaan Masyarakat

Pemberdayaan atau pemberkuasaan (empowerment), berasal dari kata 'power' (kekuasaan atau keberdayaan). Karenanya, ide utama pem berdayaan bersentuhan dengan konsep $\mathrm{m}$ engenai kekuasaan.. Kekuasaan seringkali dikaitkan dengan kem am puan kita untuk m em buat orang lain $\mathrm{m}$ elakukan apa yang kita inginkan, terlepas dari keinginan clan $\mathrm{m}$ inat mereka.

Pemberdayaan menunjuk pada kemampuan orang, khususnya kelom pok rentan dan lemah sehingga mereka memiliki kekuatan atau kemampuan dalam (a) memenuhi kebutuhan dasarnya sehingga mereka memiliki kebebasan (freedom), dalam arti bukan saja bebas mengemukakan pendapat, melainkan bebas dari kelaparan, bebas dari kebodohan, bebas dari kesakitan; (b) menjangk au sumber-sumber produktif yang memungkinkan mereka dapat $\mathrm{m}$ eningkatkan pendapatannya dan memperoleh barang-barang dan jasa-jasa yang mereka 
perlukan; dan (c) berpartisipasi dalam proses pembangunan dan keputusan-keputusan yang mempengaruhi mereka.

Dengan berbagai upaya dan indikator yang dapat dilakukan di atas, maka harapannya akan dapat tercapai pertumbuhan ekonomi dimana pertumbuhan ekonomi ini merupakan sarana untuk mencapai keadilan distributive, karena mampu menciptakan lapangan pekerjaan yang baru, dengan terciptanya lapangan kerja baru maka pendapatan riil masyarakat akan meningkat, dan ini me.rupakan salah satu indicator kesejahteraan. Dengan adanya aktivitas ekonomi, maka seseorang dapat memenuhi kebutuhan hidupnya, menciptakan kesejahteraan bagi dirinya dan keluarganya serta dapat membantu orang lain yang sedang membutuhkan.

\section{KESIMPULAN DAN SARAN}

\section{Kesimpulan}

Kesimpulan kegiatan PKM ini, agar dapat melahirkan berbagai solusi dalam rangka peningkatan kesejahteraan masyarakat diantaranya yaitu : kerjasama antara pemerintah dan masyarakat, penyaluran zakat, pertumbuhan ekonomi, nilai nilai Spiritual, pengembangan masyarakat dan pemberdayaan masyarakat.

\section{Saran}

Peran pemuda dan masyarakat sangat dibutuhkan dalam pembangunan manusia Indonesia dan upaya penngkatan kesejahteraan. Pemuda merupakan usia produktif yang tidak boleh disia siakan, maka dalam masa pandemi covid seperti sekarang ini, perlu dilakukan terobosan terobosan dalam mencari pendapatan dengan saran melakukan penjualan online dengan kekuatan pemasaran berbasis digital dan technologi dengan memanfaatkan media sosial, youtube dan market place.

\section{DAFTAR PUSTAKA}

Abdurrahman, I. K. (1994). Muqaddimah Ibnu Khaldun. Beirut: Muassasah Al Kutub Ats Tsaqafiyah.

Amirus, S. (2015). Konsep Kesejahteraan Dalam Islam. EQUILIBRIUM. Jurnal Ekonomi Syariah. 3(2).

Brehahama, A., \& Listyandini, R. A. (2016). Tingkat Kesejahteraan Psikologis Penyandang Tunatetra Dewasa Muda. Jurnal Mediapsi.2(1), 1-10.

Dewi, D. S. (2016). Model Pemberdayaan Masyarakat Tunagrahita di Kampung Idiot Kabupaten Ponorogo. Jurnal Otoritas: Jurnal Ilmu Pemerintahan. 6 (1), 21-27.

Dewi, I.K., Ahyani., Sudarso, A.P., Liawati., \& Widowati. (2020). PENGELOLAAN HASIL PERTANIAN DALAM MENINGKATKAN HARGA JUAL PADA PETANI DI DESA CICALENGKA KECAMATAN PAGEDANGAN KABUPATEN TANGERANG - BANTEN. DEDIKASI PKM. 1 (3).

Dumilah, R., Sunarto, A., Solihin, D., \& Maulida, H. (2020). Pelatihan Pemanfaatan Media Sosial Untuk Promosi Usaha Atau Bisnis Bagi Siswa. DEDIKASI PKM, 1(1), 26-33.

Mardiana, S., Supriyatna, W., Hasanah, Y. M., Zakaria., \& Indirasari, I. (2010). Optimalisasi Anggaran Keuangan Di Masa Pandemi Pada Desa Cicalengka Kabupaten Pagedangan Tangerang. DEDIKASI PKM. 1 (3).

Ofuani, A. I. (2011). The Right to Economic Empowerment of Persons with Disabilities in NIgeria : How Enabled? African HUman Rights Law Journal, 639-658. 
Qurbani, D., Mardiana, S., \& Nugroho, R. D. (2020). Meningkatkan Minat Dan Potensi Generasi Milenial Khususnya Siswa-Siswi SMK Darussalam Untuk Memulai Bisnis Online Dengan Sistem Dropship. DEDIKASI PKM. 1 (3).

Prilleltensky, O. (2004). Motherhood and Disability ; Children and Choices. Newyork: Palgrave Macmillan.

Sabah, Noor Us. (2019). Social Welfare and Role of women in muslim society (From Historical Perspective). Proceeding of The 14th ISDEV International Islamic Management Conference (IDMAC 2019) ISBN 978-967-394-339-5

Sirajudin, A. (2005). The Strugle for recognition : Embracing the Islamic Welfare Effort in the Indonesian Welfare System. Studi Islamika. Indonesian Journal For Islamic Studies. 12(1).

Solihin, D., Susanto, N., Setiawan, R., Ahyani, \& Darmadi. (2020). PENERAPAN STRATEGI PEMASARAN SEBAGAI UPAYA MENINGKATKAN USAHA KECIL DAN MENENGAH WARGA DI KELURAHAN PANINGGILAN UTARA CILEDUG. ABDI LAKSANA, 1(3), 351-355.

Solihin, D., Prasetiyani, D., Sari, A. R., Sugiarti, E., \& Sunardi, D. (2020). PEMANFAATAN BOTOL BEKAS SEBAGAI PENYARING AIR BERSIH SEDERHANA BAGI WARGA DESA CICALENGKA KECAMATAN PAGEDANGAN KABUPATEN TANGERANG. DEDIKASI PKM, 1(3), 98-102.

Suharto, E. (2014). Membangun Masyarakat Memberdayakan Rakyat Kajian Strategis Pembangunan Kesejahteraan Sosial dan Pekerjaan Sosial. PT. Refika Aditama, Bandung.

UU. (2009). Undang Undang republik Indonesia Nomor 11 Tahun 2009 tentang kesejahteraan sosial . Jakarta.

UU. (2019). Undang Undang Republik Indonesia no 14 Tahun 2019 Tentang Pekerja Sosial. Jakarta.

Wasserman, D., Bickenbach, J., \& Wachbroit, R. (2005). Quality of LIfa and HUman Difference ; Genetic, Health care, and Disability. Newyork: Cambrige University Press. 